\title{
Circulating nucleic acids as a diagnostic and prognostic marker in various malignant and benign diseases
}

\author{
S. SOOD ${ }^{1 *}$ and S. PURI ${ }^{2}$ \\ ${ }^{I}$ Departments of Biochemistry, Government Medical College \& Hospital, Sector 32, \\ Chandigarh -160031 India. \\ ${ }^{2}$ Biotechnology, U.I.E.T., Panjab University, Chandigarh-160014 India. \\ *Corresponding author, E-mail : sush_sood64@yahoo.co.in
}

\begin{abstract}
Elevated levels of circulating nucleic acids have been found in a variety of benign and malignant pathological conditions. The ability to detect and quantitate specific DNA, RNA and micro-RNA sequences in serum/ plasma has opened up the possibilities of non-invasive diagnosis and monitoring of diseases. Circulating nucleic acids have now been shown to be useful in other conditions, such as diabetes mellitus, stroke and myocardial infarction. Plasma DNA is already in use for fetal blood group typing in many countries. With the rapid development in molecular biology techniques the application of circulating nucleic acids in diagnostics especially in cancer and prenatal diagnosis is expected to be revolutionized.

(c) 2010 International Formulae Group. All rights reserved.
\end{abstract}

Keywords: Epigenetics, cancer, fetal DNA, MicroRNA, Pre-natal diagnosis, Real time PCR.

\section{INTRODUCTION}

Circulating nucleic acids (DNA and RNA) are nuclear macromolecules that can exist in an intracellular and extracellular form. The spontaneous release of DNA and RNA from living cells has been demonstrated frequently during the past 50 years. Increased levels of circulating nucleic acids (NA) in circulation are associated with cell death as a result of tissue injury or inflammatory reaction. It is also suggested that cell free circulating NA are derived from both cell apoptosis and necrosis with only a small amount coming from T-cells (Giacona et al., 1998; Stroun et al., 1989). Recently much interest has developed in the use of cell free NA for clinical purpose in many benign and malignant conditions such as cancer, pregnancy, trauma, myocardial infarction (MI) and diabetes etc. This is because medicine is slowly advancing towards noninvasive diagnostic and therapeutic approaches as current diagnostic procedures are not good at detecting early disease and require invasive investigation. This article reviews some of the potential applications of circulating NA as an early diagnostic and prognostic marker in the management of cancer and pregnancy related complications, of tissue injury in trauma, stroke and many others. Further, some of the techniques regarding the quantification of circulating NA have also been discussed. 


\section{CLINICAL IMPLICATIONS Cancer}

Cancer is driven by the accumulation of genetic changes that provide many opportunities to detect the presence of neoplastic cells in body fluids that drain or bathe the affected organs. Yet blood, the only fluid in direct contact with all bodily organs, remains the most attractive for cancer detection. Among the cancer markers measurement of circulating DNA driven from primary tumor seems to be more promising. It is well known that cancer development is associated with the progressive accumulation of genetic and epigenetic alterations. These events can include allelic loss, microsatellite instability, point mutations, amplification, translocation, gene promoter region hypermethylation. Circulating DNA found in cancer patients has many characteristics in common with their tumors, which made it an attractive candidate for use in the diagnosis and management of patients with malignancies. Further this method can also be applied to the assessment of the subclinical tumor burden in cancer patients, thus reducing the risk of unnecessary chemotherapy.

\section{Targets for cancer detection k-ras}

Mutated ras genes were the first tumor specific gene sequences detected in the blood from patients with cancer. Early workers suggested the presence of N-ras in the blood of patients with leukemia and mylodysplasia (Vasioukhin et al., 1994) and the presence of mutated K-ras sequences in blood of patients with pancreatic cancer (Mulcahy et al., 1998). However there are certain limitations of using K-ras as biomarker. In many cases the mutations that have been detected in plasma DNA came from patients with advanced metastases disease. This limits the potential role of this approach in early diagnosis, although occasionally cases have been described in which the mutation was detected in several months before clinical diagnosis (Johnson and Lo, 2002).

\section{Microsatellite alterations (MA)}

All tumors however do not have high mutation rates on easily testable hot spots. This is the reason why several groups looked for MA in the plasma/serum DNA of cancer patients.

Microsatellites are highly polymorphic DNA repeat regions ranging in number from 2 to 6 base pairs. Alterations of the Microsatellite DNA are an integral part of neoplastic progression and are valuable as clonal markers for the detection of human cancer.

Microsatellite alterations (MA) comprising loss of hetrozygosity (LOH) as well as microsatellite instability (MSI) and generally matching those of the primary tumors have been found in circulating DNA of $27-88 \%$ of lung cancer patients and in $48-94 \%$ of patients whose tumors were known to be positive for the markers. Many of the lung cancer studies used 2 to 5 markers except for 2 studies, which used 12 and 16 markers. The best sensitivity for detecting MA in plasma DNA was reported by Beau-Faller et al. (2003); who used a series of 12 markers. In recent studies MA was used to detect tumor specific circulating DNA alterations in urine sediment samples of patients with transitional cell carcinoma (TCC) of the urinary bladder (von Knoblock et al., 2001). Early breast cancer patients were analysed using 8 microsatellite markers. 12 out of 56 patients (21\%) demonstrated $\mathrm{LOH}$ in their serum for at least one marker which correlated with histopathology of the tumor (Taback, 2001).

MSI and LOH in circulating DNA is attractive because direct comparison can be made with genomic leukocyte DNA from the same blood sample, but it can be difficult to achieve accurate and satisfactory results because the circulating DNA is not exclusively derived from tumor cells. Therefore false negative results are possible.

Disadvantages of microsatellite alterations

Although MA is powerful in the determination of deletions of chromosome regions in lesions with clonal cell populations, many factors may interfere with the analysis 
and data interpretations such as marker selection, normal cell contamination, protein digestion and isolation protocol etc.

\section{DNA integrity}

Recently it was shown that integrity of circulating DNA, measured as the ratio of longer to shorter DNA fragments is higher in patients with gynecological and breast cancers than in normal individuals (Wang, 2003). The premise is that apoptotic cells release DNA fragments that are usually 185-200 base pairs in length. In healthy individuals the main source of free circulating DNA is apoptotic cells. In contrast DNA released from malignant cells varies in size because pathologic cell death in the malignant tumors results not only from apoptosis, but also necrosis, autophagy or mitotic catastrophe. Therefore elevated levels of long DNA fragments could be a good marker for detection of malignant tumor in blood. Umetani et al. (2006) had developed a simple and highly sensitivity method to directly measure the serum DNA integrity based on quantitative real time PCR. In this assay the purification of DNA from serum was unnecessary. The absolute levels of serum DNA have been demonstrated to be a potential indicator for cancer existence. Further, it was realized that serum DNA integrity had a higher correlation coefficient value with tumor progression than the absolute level of serum DNA. Therefore, serum DNA integrity was considered a better representative for cancer progression. Evaluation of serum DNA integrity achieved $69 \%$ sensitivity for detection of AJCC stage II to IV primary breast cancer with specificity of $80 \%$ and sensitivity of $74 \%$ for LN metastasis of primary breast cancer with specificity of $80 \%$ (Gal, 2004).

The DNA clearance rate of the patient could directly contribute to the absolute serum DNA level. In contrast, it would not significantly influence values of DNA integrity because both the amounts of longer and shorter DNA fragments would be similarly affected. Unlike absolute DNA levels which do not reflect how DNA is released, DNA integrity specifically represents the relative amount of non apoptotic cell death.

\section{Epigenetics}

Heritable changes in gene function that cannot be explained by changes in DNA sequence are termed epigenetic. Whereas point mutations and $\mathrm{LOH}$ result in failure of expression of tumor suppressor genes, epigenetic alterations cause silencing of expressions of the tumor suppressor genes. The stable nature of epigenetic silencing has led to the hypothesis that it constitutes a viable mechanism of inactivating tumor suppressor genes in cancers. Various epigenetic processes include DNA methylation, post translational modification of histones and RNA interference. Promoter region hypermethylation has been described as a common genetic abnormality occurring in various cancers (Gal, 2004).

Epigenetic abnormalities, such as aberrant methylation of $\mathrm{CpG}$ islands are inherited over cell divisions, and play important roles in carcinogenesis. Aberrant methylation of $\mathrm{CpG}$ islands specific to tumor cells can be used as a marker to detect cancer cells or cancer-derived DNA. Methylation of specific genes or methylation patterns of groups of genes were found to be associated with responses to chemotherapeutics and prognosis. Methylation in non-cancerous tissues is now attracting attention as a tumor risk marker, and is emerging as a target for cancer prevention as epigenetic alterations are potentially reversible. The use of DNA demethylating agents has turned out to be effective for hematological malignancies, and is being tested in solid tumors. Histone deacetylase inhibitors and methods for genespecific epigenetic modification are being developed. Application of epigenetics to cancer diagnostics and therapeutics, and possibly to cancer prevention, is coming into clinics (Gerda et al., 2004; Issa, 2007)

Many authors have reported the aberrant methylation of CGIs in promoter regions of tumor-suppressor genes, such as 
RB, p16, VHL, hMLH1, E-cadherin and BRCA1 which are known to be involved in their inactivation in various cancers, including stomach, colon, liver, breast, uterine, renal and hematological tumors (Kazuaki and Toshikazoo, 2005) as shown in Table-1

\section{Advantages of DNA methylation over mutations as a marker}

Firstly, incidences of aberrant methylation of specific CGIs are higher than those of mutations and such methylation can be discovered by genome-wide screening procedures. Secondly, aberrant methylation of a DNA molecule can be sensitively detected; even when it is embedded in an excess amount of normal DNA molecules .Thirdly, detection of aberrant methylation is technically simple. Aberrant methylation usually takes place in an all-or-nothing manner, and it can be detected using only one set of PCR primers. On the other hand, mutations can take place in various regions of a gene, and many primer sets are necessary for complete analysis. Finally, some aberrant methylation is observed in early stages of carcinogenesis and even in non-neoplastic tissues. For example, methylation of non-core regions of $\mathrm{p} 16$ is observed in pulmonary hyperplasia $(17 \%)$, dysplasia (24\%), and lung carcinoma in situ $(50 \%)$ as suggested by Kazuaki and Toshikazoo (2005).

\section{Serum / plasma viral DNA}

An additional source of DNA in plasma is that originating from viruses, and when these viruses have a close association with a particular cancer, they have the potential to be used as molecular markers as viral DNA is relatively easy to quantify. Particular viral sequences have been reported in circulation in patients suffering from some Epstein-Barr virus (EBV) associated cancers (nasopharyngeal carcinoma, EBV-associated Hodgkin'sdisease) as has circulating human papilloma virus (HPV) DNA sequences in plasma of cervical cancer patients associated with metastasis (Pornthanakasem, 2001). Unfortunately, the viral genome is not distinguishable between patients with hepatoma and chronic hepatitis, limiting the usefulness of detecting viral hepatitis DNA as a tumor marker (Lin, 2004).

\section{Fetal DNA}

Lo et al. (1997) discovered circulating DNA in maternal plasma that has opened up new possibilities for non invasive prenatal diagnosis. There is a common perception that fetal blood remains separated from maternal blood until third stage of labor or following abortion, inversion of placenta etc and only IgG can cross the placental barrier due to its small molecular weight. However, recent observations suggest that the placental barrier is not as impermeable as is traditionally known. This is because fetal DNA has been detected in maternal blood as early as 5 weeks. RT-PCR is sensitive enough to detect the DNA equivalent of a single cell - a male fetal cell against a background of 12,800 female cells (Biswajit, 2004).

As a standard practice, DNA based investigations are done from tissues obtained by chorionic villus sampling (CVS) or cells by amniocentesis. Both are invasive techniques requiring expertise to perform and carry little but definite risks. Maternal plasma is a chimeric mixture of fetal and maternal DNA and fetal DNA in maternal blood comes from continuous leakage of fetal cells (trophoblasts, nucleated red blood lymphocytes, granulocytes and stem cells). Over the last few years, this noninvasive source of fetal DNA has been used for the prenatal diagnosis of sex linked disorders, fetal RhD status, $\beta$ thalassemia, congenital adrenal hyperplasia and other diseases. Furthermore, quantitative aberrations of circulating fetal DNA have been described in a variety of pregnancy associated disorders, including pre-eclampsia, trisomy21, preterm labor, hypermesis gravidarum, and invasive placentation (Lo, 2006).

There are very few studies on the factors that influence cell-free DNA levels in normal pregnancies. Bianchi (1998) has examined the effect of gestational age, race, 
parity, smoking history and type of conception (natural or assisted). They showed that gestational age is a significant factor affecting the fetal DNA levels. Fetal DNA levels increase by $21 \%$ per week in the first trimester. Smoking and maternal age has no influence on the fetal DNA concentration. There was a significant inverse correlation between maternal weight and fetal DNA levels (Wataganara et al., 2004). There was a difference in the fetal DNA according to the type of conception (Pan et al., 2005).

\section{DIAGNOSTIC USEFULNESS} Circulating DNAs for fetal aneuploidies

It was suggested that the circulating fetal DNA (fDNA) levels in pregnant women carrying a fetus with trisomy 21 were elevated. Using serum DNA alone 21\% Down syndrome affected pregnancies were detected at a $5 \%$ false positive rate. This performance is very similar to that of alpha fetoprotein alone. By incorporating fDNA analysis into the current quadruple panel (alpha fetoprotein, human chorionic gondotropin, unconjugated estriol and inhibin-A) screening performance was modestly improved from $81 \%$ to $86 \%$ at a $5 \%$ false positive rate (Farina, 2003). This initial feasibility study was limited by fetal gender. Further work showed that circulating fDNA levels were elevated in pregnant women carrying a fetus with trisomy 13 but not with trisomy 18 (Wataganara et al., 2003). Later on it was shown that trisomy 18 can also be detected in pregnant women using fetal DNA by making use of epigenetic allelic ratio ( EAR) analysis (Tong, 2006).

\section{Sex determination}

Sex determining region of the $\mathrm{Y}$ chromosome (SRY) is a unique feature of a male. Normally, maternal DNA does not contain SRY. Hence demonstration of SRY by PCR in maternal plasma during pregnancy indicates existence of a male fetus. Fetal sex determination is obviously useful for $\mathrm{X}$ linked recessive disorders. Detection of paternally inherited chromosome polymorphism and aneuploidies of female fetus by informative short tandem repeat, SRY, markers have been made possible from maternal plasma (Biswajit, 2004).

\section{CIRCULATING DNA AND GYNAECOLOGIC COMPLICATIONS Pre-eclampsia (PE)}

The approximately 5 fold elevation of circulating fDNA levels in symptomatic women with pre-eclampsia has been reported. It may be possible to use fetal DNA as a marker to monitor severity of $\mathrm{PE}$ in proteinuria or hypertension as clinical evidence of PE. It was seen that both proteinuria and hypertension were independently and strongly associated with increased concentration of fetal DNA in maternal plasma, the extent to which depended on the severity of each symptom (Sekizawa, 2004). Proteinuria was associated with greater increases in fetal DNA than hypertension. As fetal DNA is also thought to come from villous trophoblasts and is associated with severity of PE, fetal DNA might represent a molecular marker that can be used to evaluate trophoblast damage and monitor the status of pregnancy affected by $\mathrm{PE}$ in clinical practice. It is also reported that asymptomatic pregnant women who eventually develop pre-eclampsia also had higher than expected plasma fDNA levels. The exact reason for the relationship between pre-eclampsia and elevation of circulating DNA is yet to be elucidated. It may be due to the combined effect of increased liberation from abnormal placenta and reduced fDNA clearance resulting from an impairment of liver and kidney function later in the disease process. This fact is clear from the studies where median half life of fetal DNA clearance was reported to be 114 minutes which was significantly prolonged as compared with the median half life of 28 minute in normal pregnancies (Lo et al., 1999).

\section{Fetal RH (rhesus) D status}

Fetal $\mathrm{RhD}$ status has been predicted with $99.5 \%$ accuracy using fetal DNA. The International Blood Group Reference 
Laboratory (IBGRL) provides a fetal blood genotyping service to obstetrician managing the pregnancies of alloimmunized women in the U.K. Originally this involved Polymerase Chain Reaction (PCR) amplification of fetal DNA extracted from aminocyte or chorionic villi which carried a small risk of inducing spontaneous miscarriage and a significant risk in alloimmunized women. The introduction of a clinical test to determine fetal D blood grouping from maternal plasma has significantly reduced the number of invasive procedures carried out in the UK for fetal D blood grouping as shown in Figure 1 (Finning, 2004)

\section{Congenital adrenal hyerplasia (CAH)}

In case of $\mathrm{CAH}$, early prenatal diagnosis can shorten the maternal dexamethasone therapy so as to prevent the virilization of the female fetus (Rijnders, 2001).

\section{Fetal DNA marker}

Fetal DNA circulates in the maternal plasma among a high background of maternal DNA sequences. Because Y-chromosome DNA sequences are readily distinguishable from the background maternal plasma DNA, most investigators have thus far relied on the use of such sequences as fetal specific marker and have reported the association of abnormal concentration of circulating fetal Ychromosome DNA with a number of pregnancy related complications. However, the current approach based on Ychromosomal DNA analysis cannot be used for the $50 \%$ of pregnancies involving female fetuses, thus hindering observations into the realms of clinical use.

Investigators have further explored the use of genetic polymorphism. However, exploring genetic polymorphism greatly increases the complexity of the resulting tests because multiple genetic markers would be needed to correlate the results. While the absolute concentration of circulating DNA has been reported by a number of groups to be elevated in pregnant women carrying fetuses affected by trisomy 21, this approach will only result in a relatively nonspecific screening method for this fetal chromosomal aneuploidy, as many other conditions such as pre-eclampsia are also associated with an elevated level in circulating fetal DNA. The exploration of new approaches for the noninvasive prenatal diagnosis of fetal chromosomal aneuploidies using circulating fetal DNA is therefore important.

So keeping in mind, the limitations of genetic markers and requirement of a fetal DNA marker that could be detected in all pregnancies led to the finding of epigenetic markers. The central requirement for such a marker is that it should exhibit different methylation pattern depending on whether it is originating from fetal or maternal tissue. It was suggested that a region of DNA, which is methylated if inherited from the father and unmethylated if inherited from the mother, could be used to differentiate fetal origin of DNA in circulation. U-maspin is such a gene. It is a tumor suppressor gene expressed in placenta. Maspin gene is hypomethylated in the placenta but hypermethylated in the maternal blood cells. Hypomethylated maspin promoter sequences were also present in the plasma of pregnant women and they were rapidly cleared after delivery. In general a higher proportion of hypomethylated maspin promoter sequences were observed in the third-trimester placental tissues compared with first trimester placental tissues which suggest that there is a change in the methylation density of maspin promoter as gestation progresses. The concentration of hyomethylated maspin in the circulation was elevated nearly six times in the plasma of women suffering from pre-eclampsia proving that hypomethylated maspin could be a very useful fetal DNA marker (Lo, 2006).

\section{Size}

Another approach to detect fetal cell free DNA in maternal plasma is to examine the size. It was shown that fetal cell free DNA is smaller than comparable maternal cell free DNA molecules and majority of fetal 
DNA had a molecular size of less than $300 \mathrm{bp}$ whereas most of the maternal DNA was greater than $300 \mathrm{bp}$. This finding suggests that fetal cell-free DNA could be enriched on the basis of size. By isolating the cell free DNA from maternal plasma according to size and using an allele specific real time PCR based approach they demonstrated the feasibility of detecting $\beta$ thalassemia in maternal plasma ( $\mathrm{Li}$ et al., 2004).

\section{Epigenetic allelic ratio analysis (EAR)}

Prenatal diagnosis of a human chromosomal abnormality by Tong et al. (2006) describes a novel approach to the non invasive analysis of the allelic ratio of a polymorphism present within the methylated promoter of a DNA sequence on chromosome 18 q 21.3, maspin (SERPINB5). This method differs from other approach to non invasive diagnosis of aneuploidy in that it is truly diagnostic, as opposed to being a screen.

A single base variation (or single nucleotide polymorphism (SNP) within the promoter sequence is used as a focus for mass spectrometric analysis, with subsequent analysis of the ratio of copy numbers of the particular DNA sequence variation. U-maspin 156 SNP was used. A normal euploid fetus might be genotyped as AC at this locus. Fetuses with trisomy 18, if polymorphic, would be genotyped as having AAC or ACC. By measuring the ratio of $\mathrm{A}$ to $\mathrm{C}$, a euploid fetus would have 1 , and a trisomy 18 fetus would theoretically have 2 or 0.5 . It is important to recognize that methylated maternal cell free DNA which derives mainly from blood cells, does not co-amplify in the methylation specific PCR. In this study 173 euploid placentas were genotyped for polymorphism at the U-maspin 156 site. Of these only $31 / 173(17.9 \%)$ were informative. Significant ethnic variations were observed. The authors did not find the $\mathrm{C}$ allele in 129 placentas obtained from caucasians but did observe it in Chinese and Africans. This suggests that extensive SNP analysis and a thorough characterization of population specific variation must provide clinical application of EAR analysis in maternal plasma.

\section{RELATIVE CHROMOSOME DOSAGE ANALYSIS}

The main disadvantage of the allelic ratio-based approach is the requirement that the fetus be heterozygous for the analyzed genetic polymorphisms. To overcome the requirement for heterozygosity, methods that directly measure the relative dose of different chromosomes are required. An alternative solution is the development of analytical strategies that can perform relative chromosome analysis despite the low fractional concentration of circulating fetal DNA in maternal plasma. In this regard, the digital PCR-based approach can be applied for chromosome dose analysis, the so-called digital relative chromosome dose approach. In this method, digital PCR analysis is carried out for 1 or more targets located on a chromosome involved in a trisomy (e.g. chromosome 21) and for 1 or more targets located on a reference chromosome not involved in the trisomy. Digital relative chromosome dose measurement has been demonstrated to possess the discrimination power to detect the presence of DNA from a trisomic fetus, even if the trisomic DNA constitutes only some $10 \%$ of the tested sample (Lo, 2008).

\section{Fetal RNA}

Placenta is an important source of fetal RNA in maternal plasma. mRNA species of human placental lactogen (hpL), the $\beta$ subunit of human chorionic gonadotropin ( $\beta \mathrm{hCG}$ ), corticotropin release hormone $(\mathrm{CRH})$ have been found in maternal plasma. $\mathrm{Ng}$ et al. (2003) have shown that CRH mRNA concentrations are greatly elevated in preeclamptic patients, when compared with control pregnant women matched for gestational age.

Wong et al (2005) studied the integrity of plasma RNA using GAPDH transcript in the plasma of healthy non pregnant individuals by comparing multiple regions ( 5 , 
middle and 3' regions) within the transcript and suggested that GAPDH mRNA population is predominantly 5'-fragments rather than intact transcripts. The same results were obtained from transcript of $\beta-h C G$, TFp12, ADM, 1NHBA, PAPA, PLAC 1. The origin of the 5'mRNA fragments in maternal plasma is likely to be associated with the mechanism of mRNA degradation. This information could be used to improve the rate of placental RNA detection in the maternal plasma, thus facilitating the establishment of more molecular markers for pregnancy associated diseases, including pre-eclampsia and fetal chromosomal aneuploidies. Measurement of circulating fetal RNA has the advantage that it can be applied to all pregnancies irrespective of fetal gender or polymorphism between mother and fetus.

\section{Advantages of fetal DNA / RNA}

The main advantages of the molecular assays are that within 24-36 hours from the collection of the samples it is possible to inform the parents about the results thus relieving their anxiety if the fetus is found to be normal or allowing prompt interruption of pregnancy if the fetus is affected by a major chromosome abnormality.

\section{Critical illiness}

Circulating plasma DNA concentration increased with in hour after injury and may increase by as much as 100 fold in those patients who go on to develop organ failure. Compared with patients with uncomplicated injury, there is a 10-18 fold increase in median plasma DNA concentrations in those patients who develop failure, multiple organ dysfunction syndrome, acute lung injury and who die. In patients admitted to ICU, plasma DNA concentrations are persistently elevated in those patients who develop a complicated course characterized by organ failure compared with patients with an uncomplicated course (Rainer and Lam, 2006).

\section{Stroke}

Although elevated level of several neuro-biochemical markers, protein markers have been detected in the peripheral blood of patients with stroke, so far none have found a place in routine clinical practice. Circulating plasma DNA concentration are elevated early after the onset of stroke, are related to the extent of brain damage, and may be used to predict short and long term neurobehavioral morbidity and post stroke mortality. Plasma DNA concentration is also higher within 6 hour of symptom onset in patients with hemorrhagic stroke compared with patients with ischemic stroke (Antonatos, 2006).

\section{TRANSPLANT REJECTION}

Despite HLA matching and the introduction of new immunosuppressive drugs, acute allograft rejection is one of the major complications of transplantation. Measurement of donor specific DNA or measurement of mRNA for granulysin and FOX P3 in urine has been found to be a useful predictor of kidney transplant rejection (Kotsch et al., 2004; Muthukumar et al., 2005).

\section{CIRCULATING NUCLEOSOMES}

Elevated levels of circulating nucleosomal DNA were found in various benign and malignant pathological conditions e.g, after exhaustive sports, trauma, ischemia, sepsis, graft rejection, autoimmune diseases and numerous neoplastic diseases. It showed that measurement of nucleosomes together with other tumor markers can be useful in predicting the outcome of chemotherapy. Knowledge about the specific role of circulating nucleosomal DNA in the pathogenesis of many diseases is scarce. Only systemic lupus erythematosus (SLE) has been investigated more intensively as nucleosomes are supposed to be the major immunogens in SLE (Holdenrieder et al., 2006).

\section{CIRCULATING MITOCHONDRIAL DNA (mtDNA)}

Mutations in the mitochondrial genome are associated with various diseases. Mutant mtDNA has been detected in the plasma of patients with diabetes mellitus (Zhong, 2000), hepatocellular carcinoma (Nomoto, 2002) and 
stroke (Lam et al., 2004). However, there is paucity of data on circulating mtDNA.

\section{PLASMA RNA}

The origin of circulating RNA (cir RNA) is not clear to date. The extracellular RNA appears to be heavily methylated, associated with DNA, single stranded, of low molecular weight (2.5-4S) and was not tRNA. The total amount of RNA in human plasma is found to be $144 \mathrm{ng} / \mathrm{ml}$. Further it was found that the shedding capacity of highly metastatic cell line was much higher than that of the cell line with low metastatic capacity (Fleischhacker, 2006).

The theoretical advantage of plasma DNA detection is that the RNA approach would provide valuable information on the gene expression patterns of the tumor or fetus. If the technology can be performed robustly and on multiple genes simultaneously, this would allow the performance of non-invasive gene expression profiling by using peripheral blood of cancer patients or pregnant women.

Wong et al. (2004) observed a correlation between the increased amount of circulating $\beta$-catenin mRNA and the presence of a tumor of the colorectum. By quantification of $\beta$-catenin mRNA they could also differentiate between patients with tumor and with an adenoma and healthy controls. Plasma $\beta$-catenin mRNA concentration was correlated to tumor stage only. There are only two reports in which tumor- associated mRNA in plasma was analysed in patients before and after therapy, i.e. in lung cancer patients (Fleischhaekerz et al., 2001) (using Her-2/neu and hnRNP-B1mRNA) and in prostate cancer patients (Papadopoulou et al., 2004) (using PSMA and CEA mRNA).

Telomerase activity is one of the most promising general tumor makers. Increased presence of circulating human telomerase reverse transcriptase (hTERT) mRNA in the patients suffering from the tumor of colorectum as compared to control group was suggested but there was no association of hTERT mRNA with tumor stage. The clinical usefulness of telomerase depends on the ability of its detection in the biological fluids such as blood, urine, sputum or bronchoalveolar lavage (BAL). Telomerase activity is strongly associated with prostrate cancer showing activation in a high percentage (70-93\%) of prostate tumors (Dasi et al., 2006). The detection of tumor associated over expressed mRNA in plasma/ serum of patients with liver, thyroid, melanoma or breast cancers has been reported by many investigators as shown in Table 2 .

Circulating mRNA for rhodopsin and nephrin was detectable in healthy and diabetic patients. Rhodopsin mRNA was significantly raised in diabetic patients with retinopathy and nephrin mRNA was increased in diabetic nephropathy. Higher rhodopsin mRNA in diabetic patients without retinopathy suggests that some of them may develop it or already have it subclinically (Butt, 2006). Chan et al. (2010) hypothesized that liver-derived mRNA, such as $A L B$ (albumin) mRNA, would be released into human plasma with the death liver cell. $A L B$ mRNA is liver specific in plasma, but not in whole blood. Plasma $A L B$ mRNA is increased in some liver pathologies and may be more diagnostically sensitive than $a$-fetoprotein and ALT.

As total DNA is nonspecific and does not localize the tissue, the detection of organ specific mRNA is thought to be better. But it is still to be confirmed whether the RNA quantification as a stand -alone method could be a clinically useful tool. The answer to it will very much depend on the development of new research tools.

\section{CELL-FREE NUCLEIC ACIDS IN THE URINE}

It has been shown that small amounts of cell free circulating nucleic acids from the blood can pass through the kidney barrier into the urine. Tumor specific sequences were detected in DNA isolated from urine of patients with tumors of different localizations. 
Table 1: Detection of cancer-derived DNA in plasma/serum by DNA methylation.

\begin{tabular}{|c|c|c|c|c|c|c|}
\hline Tumor & $\begin{array}{c}\text { Speci } \\
\text { men }\end{array}$ & Gene & $\begin{array}{c}\text { Quantitative } \\
\text { analysis }\end{array}$ & $\begin{array}{c}\text { Incidence } \\
(\%)\end{array}$ & Control & References \\
\hline \multirow[t]{7}{*}{ NSCLC } & $\mathrm{S}$ & $\begin{array}{c}\text { p16*, DAPK, GSTP } \\
1, \text { and MGMT }\end{array}$ & No & $11 / 22(50)$ & N/A & Esteller et al. (1999) \\
\hline & $\mathrm{P}$ & $\mathrm{p} 16$ & No & $1 / 10(10)$ & N/A & Kurakawa et al. (2001) \\
\hline & $\mathrm{P}$ & p16 & No & $77 / 105(73)$ & N/A & An et al. (2002) \\
\hline & $\mathrm{P}$ & p16 & No & $12 / 35(34)$ & $0 / 15^{\#}$ & Bearzatto et al. (2002) \\
\hline & $\mathrm{P}$ & p16 & No & $2 / 33(6)$ & N/A & Ng et al. (2002) \\
\hline & $\mathrm{P}$ & p16 & No & $103 / 136(76)$ & N/A & Liu et al. (2003) \\
\hline & $\mathrm{S}$ & APC & Yes & $42 / 89(47)$ & $0 / 50^{\# \#}$ & Usadel et al. (2002) \\
\hline \multirow[t]{4}{*}{ Head and neck } & $\mathrm{S}$ & p16, DAPK and MGMT & No & $21 / 50(42)$ & N/A & Sanchez-Cespedes et al. (2000) \\
\hline & $\mathrm{P}$ & DAPK & No & $6 / 16(38)$ & N/A & Wong et al. (2002) \\
\hline & $\mathrm{P}$ & $\mathrm{p} 16$ and $\mathrm{p} 15$ & Yes & $13 / 20(65)$ & $4 / 24$ & Wong et al. (2003) \\
\hline & $\mathrm{P}$ & $\begin{array}{l}\text { E-cadherin, p16, DAPK, p15 } \\
\text { and RASSF1A }\end{array}$ & Yes & $29 / 41(71)$ & $4 / 43$ & Wong et al. (2004) \\
\hline Esophageal AdC & $\mathrm{P}$ & APC & Yes & $13 / 52(25)$ & $0 / 54$ & Kawakami et al. (2000) \\
\hline \multirow[t]{2}{*}{ Esophageal SCC } & $\mathrm{P}$ & APC & Yes & $2 / 32(6)$ & $0 / 54$ & Kawakami et al. (2000) \\
\hline & $\mathrm{S}$ & p16 & No & $7 / 38(18)$ & N/A & Hibi et al. (2001) \\
\hline \multirow[t]{4}{*}{ Breast } & $\mathrm{P}$ & p16 & No & $5 / 35(14)$ & N/A & Silva et al. (1999) \\
\hline & $\mathrm{P}$ & p16 & No & $6 / 43(14)$ & N/A & Silva et al. (1999) \\
\hline & $\mathrm{P}$ & p16 & No & $4 / 41(10)$ & N/A & Silva et al. (2002) \\
\hline & $\mathrm{P}$ & p16 and E-cadherin & No & $9 / 36(25)$ & N/A & Hu et al. (2003) \\
\hline
\end{tabular}


S. SOOD and S. PURI/Int. J. Biol. Chem. Sci. 4(5): 1860-1880, 2010

\begin{tabular}{|c|c|c|c|c|c|c|}
\hline & $S$ & APC, RASSF1A and DAPK & No & $26 / 34(76)$ & N/A & Dulaimi et al. (2004) \\
\hline \multirow[t]{3}{*}{ Liver } & $\mathrm{P} / \mathrm{S}$ & $\mathrm{p} 16$ & No & $13 / 22(59)$ & $0 / 48^{\#}$ & Wong et al. (1999) \\
\hline & $\mathrm{P} / \mathrm{S}$ & p16 and p15 & No & $17 / 25(68)$ & $0 / 55^{\#}$ & Wong et al. (2000) \\
\hline & $\mathrm{P} / \mathrm{S}$ & p16 & Yes & $23 / 29(80)$ & $0 / 35^{\#}$ & Wong et al. (2003) \\
\hline \multirow[t]{5}{*}{ Colon and rectum } & $S$ & hMLH1 & No & $3 / 19(16)$ & N/A & Grady et al. (2001) \\
\hline & $\mathrm{S}$ & P16 & No & $14 / 52(27)$ & $0 / 42$ & Zou et al. (2002) \\
\hline & $\mathrm{P}$ & p16 & No & $21 / 58(36)$ & N/A & Lecomte et al. (2002) \\
\hline & $\mathrm{S}$ & p16 & No & $13 / 94(14)$ & N/A & Nakayama et al. (2002) \\
\hline & $\mathrm{S}$ & DAPK & No & $3 / 18(17)$ & N/A & Yamaguchi et al. (2003) \\
\hline \multirow[t]{4}{*}{ Stomach } & S & $\begin{array}{l}\text { DAPK, E-cadherin, GSTP1, } \\
\text { p16 and p15 }\end{array}$ & No & $45 / 54(83)$ & $0 / 30^{\#}$ & Lee et al. (2002) \\
\hline & $\mathrm{S}$ & $\mathrm{p} 16$ & No & $6 / 60(10)$ & $0 / 16^{\#}$ & $\begin{array}{c}\text { Kanyama et al. } \\
(2003)\end{array}$ \\
\hline & $S$ & p16 and E-cadherin & No & $40 / 109(37)$ & $0 / 10$ & Ichikawa et al. (2004) \\
\hline & $\mathrm{S}$ & p16, E-cadherin and RARß & No & $18 / 41(44)$ & $0 / ?^{\#}$ & Koike et al. (2004) \\
\hline Prostate & $\mathrm{P} / \mathrm{S}$ & GSTP1 & No & $23 / 32(72)$ & N/A & Goessl et al. (2000) \\
\hline \multirow[t]{3}{*}{ Bladder } & $\mathrm{P}$ & $\mathrm{p} 14$ & No & $13 / 27(48)$ & N/A & Dominguez et al. (2002) \\
\hline & $\mathrm{P}$ & p16 & No & $2 / 27(7)$ & N/A & Dominguez et al. (2002) \\
\hline & $\mathrm{S}$ & p16 & No & $19 / 86(22)$ & $1 / 49^{\#}$ & Valenzuela et al. (2002) \\
\hline Melanoma & $\mathrm{P}$ & RASSF1A, MGMT \& RARß & No & 9/31 (29) & N/A & Hoon et al. (2004) \\
\hline
\end{tabular}

NSCLC, non-small cell lung cancers; AdC, adenocarcinoma; SCC, squamous cell carcinoma; P, plasma; S, serum; N/A: not analyzed.

- Regions potentially methylated in non-cancer cells ${ }^{\#}$ age-match unknown ${ }^{\# \#}$ age-matched.

Data reproduced with permission from Kazauaki, M and Toshikazoo M. (2005) 
Table-2: List of papers in which circulating mRNA was detected in plasma and other body fluids.

\begin{tabular}{|c|c|c|c|c|c|}
\hline & Tumor patients & $\begin{array}{c}\text { Over expressed } \\
\text { genes }\end{array}$ & $\begin{array}{c}\text { Detection } \\
\text { method }\end{array}$ & Compartment & Reference \\
\hline 1. & Melanoma & $\begin{array}{l}\text { Tyrosinase, gp100, } \\
\text { MART-1 }\end{array}$ & $\begin{array}{l}\text { Qualitative } \\
\text { RT-PCR }\end{array}$ & Plasma/ Serum & $\begin{array}{l}\text { Hasselmann } \\
\text { et al. (2001) }\end{array}$ \\
\hline 2. & $\begin{array}{c}\text { Breast, Melanoma, } \\
\text { Thyroid }\end{array}$ & hTR, hTERT & $\begin{array}{c}\text { Qualitative } \\
\text { RT-PCR }\end{array}$ & Plasma/ Serum & $\begin{array}{l}\text { Novakovic, } \\
\text { et al. (2004) }\end{array}$ \\
\hline 3. & Breast & $\begin{array}{l}\text { Mamma globins, } \\
\text { CK } 19\end{array}$ & $\begin{array}{l}\text { Qualitative } \\
\text { RT-PCR }\end{array}$ & Plasma/ Serum & $\begin{array}{l}\text { Silva et al. } \\
\text { (2001) }\end{array}$ \\
\hline 4. & $\begin{array}{l}\text { Hepatocellular } \\
\text { carcinoma }\end{array}$ & hTERT & $\begin{array}{l}\text { Qualitative } \\
\text { RT-PCR }\end{array}$ & Plasma/ Serum & Miura (2003) \\
\hline 5. & Colorectum & $\beta$-catenin & $\begin{array}{c}\text { Quantitative } \\
\text { RT-PCR }\end{array}$ & Plasma/ Serum & $\begin{array}{l}\text { Wong et al. } \\
\text { (2004) }\end{array}$ \\
\hline 6. & Colorectum & hTERT & $\begin{array}{l}\text { Quantitative } \\
\text { RT-PCR }\end{array}$ & Plasma/ Serum & $\begin{array}{l}\text { Lledo et al. } \\
\text { (2004). }\end{array}$ \\
\hline 7. & Prostrate & PSMA, CEA & $\begin{array}{l}\text { Qualitative } \\
\text { RT-PCR }\end{array}$ & Plasma/ Serum & $\begin{array}{l}\text { Papadopoulo } \\
\text { u et al. (2004) }\end{array}$ \\
\hline 8. & Lung & $\begin{array}{l}\text { Her-2 / neu, } \\
\text { hnRNP- B1 }\end{array}$ & $\begin{array}{l}\text { Qualitative } \\
\text { RT-PCR }\end{array}$ & Plasma/ Serum & $\begin{array}{l}\text { Fleischhaeker } \\
\text {. et al. (2001) }\end{array}$ \\
\hline 9. & Lung & hnRNP-B1, & $\begin{array}{l}\text { Qualitative } \\
\text { RT-PCR }\end{array}$ & Plasma/ Serum & $\begin{array}{c}\text { Sueoka et al. } \\
\text { (2005). }\end{array}$ \\
\hline 10. & Lung & $\begin{array}{c}\text { hnRNP- B1, PGP 9.5, } \\
\text { MAGE-2, Her-2, / } \\
\text { neu, aurora, } \\
\text { Pericentrin, } \\
\text { hTR, hTERT }\end{array}$ & $\begin{array}{l}\text { Qualitative } \\
\text { RT-PCR }\end{array}$ & $\begin{array}{c}\text { Cell -free } \\
\text { Bronchial } \\
\text { lavage fluid }\end{array}$ & $\begin{array}{l}\text { Schmidt et al. } \\
\text { 2004) }\end{array}$ \\
\hline
\end{tabular}

Figure 1: Reduction in the number of referrals to IBGRL for fetal D blood grouping using invasively derived fetal material, because of the introduction of a test, in 2001, which uses free fetal DNA in maternal blood. Data reproduced with permission from Kirstin et al. (2004). 
Concentrations of DNA and RNA in the urine of healthy people were independent of gender and were in the range of $6 \mathrm{ng} / \mathrm{ml}$ to $50 \mathrm{ng} / \mathrm{ml}$ for DNA and $24 \mathrm{ng} / \mathrm{ml}$ to $140 \mathrm{ng} /$ $\mathrm{ml}$ for RNA. DNA fragments of $150-400 \mathrm{bp}$ represent the main part of cell-free DNA, along with DNA fragments upto1,300bp which were found in male urine, and DNA fragments upto $19 \mathrm{Kbp}$ were found in female urine. A study carried out by Bryzgunova et al. (2006) showed the presence of same methylated promoters of RASSFIA and RARB2 genes in circulating DNA isolated from blood of breast cancer patients and cellfree DNA isolated from their urine. Due to the principle advantages of urine (large sample quantities, easy to acquire) the data obtained demonstrates the applicability of free urine DNA for the development of noninvasive tests for cancer diagnosis.

\section{MicroRNA}

Recently, a novel class of global gene regulators called microRNAs (miRNAs), were identified in both plants and animals. miRNAs can reduce protein levels of their target genes with a minor impact on the target genes mRNAs. Estimates indicate that more than 1000 human miRNAs target and downregulate at least $60 \%$ of human protein-coding genes expressed in the genome (Friedman, 2009). It is therefore not surprising that there is an unprecedented explosion in miRNA research to determine their biologic functions and disease relevance.

MicroRNAs are endogenous small (2125 nucleotides), single-stranded, and nonprotein-coding RNAs (Lau et al., 2001; Lagos-Quintana et al., 2001) that can pair with sites in 3' untranslated regions in mRNAs of protein-coding genes to downregulate their expression. Since their discovery as developmental regulators in C. elegans, they have come a long way and are currently associated with normal and diverse pathophysiological states including Parkinson's syndrome, cardiac hypertrophy, viral infection, diabetes and several types of cancer. They function in diverse biological processes, including development, differentiation, apoptosis and oncogenesis (Esau et al., 2004). miRNAs may leak into the circulating blood from injured cells and thereby serve as biomarkers for identifying the injured cell type.

Despite the established strengths of cardiac troponins for prompt and reliable detection of myocardial injury, the ability to reliably detect ischemia in the absence of myocyte necrosis and the ability to distinguish alternative causes and mechanisms of myocyte damage inflammation, oxidative stress, apoptosis led to the discovery of a new biomarker miR-208, the plasma concentration of which may be a useful indicator of myocardial injury (Xu et al., 2009).

It is found that miR-375 is essential for beta cells to survive, grow and divide. A lack of miRNA-375 causes the beta cells to die, while the producers of glucagon - the alpha cells - increase in mass. Scientists also discovered a link between this RNA strand and type- 2 diabetes. The miR-375, a regulator of numerous growth factors in the beta cell, restricts the process of pancreatic beta cell proliferation. Without miR-375, the number of beta cells reduces over time. The result is lack of insulin, which in turn leads to diabetes (Park et al., 2009; Poy et al., 2009; Pandey et al., 2009). Overwhelming evidence implicating miRNAs in the pathology of key human diseases has sparked tremendous interest in the development of modalities to block specific miRNAs and their function in vitro and in vivo. Small non-coding RNAs and miRNAs, such as miR-192 and miR-377, may be novel targets for diabetic neuropathy and other diabetic complications (Kato, 2009).

Accumulating evidence demonstrates the importance of miRNAs in cancer. MiRNAs that are overexpressed in cancer may function as oncogenes and miRNAs with tumour suppressor activity in normal tissue may be downregulated in cancer. miRNA 
expression data in various cancers demonstrate that cancer cells have different miRNA profiles compared with normal cells, thus underscoring the tremendous diagnostic and therapeutic potential of miRNAs in cancer. (Paranjape, 2009). Ng et al. (2009) reported a significant increase in miR-92 in plasma of patients with CRC and can be a potential non-invasive molecular marker for CRC screening. Approximately 50 microRNAs were detected in saliva. Two specific microRNAs, miR-125a and miR200a, were present at significantly lower levels in patients with oral squamous cell carcinoma (OSCC) than in the healthier controls. Thus the detection of miRNAs in saliva can be used as a noninvasive and rapid diagnostic tool for the diagnosis of oral cancer (Park et al., 2009). Although genetic polymorphisms have been widely implicated in cancer development and treatment response, such evidence is lacking for the miRNArelated genes. Yang et al. (2008) genotyped 41 single-nucleotide polymorphisms (SNP) from 24 miRNA-related genes in a case-control study conducted in 746 Caucasian patients with bladder cancer and 746 matched controls. The homozygous variant genotype of a nonsynonymous SNP in the GEMIN3 gene (rs197414) was associated with a significantly increased bladder cancer risk.

Placental miRNAs represent a novel class of fetal nucleic acid markers in maternal plasma. Chim et al. (2008) have shown that the plasma concentration of a placental miRNA, miR-141, increased as the pregnancy progressed into the third trimester. This increase in miR-141 in maternal plasma may reflect an increase in the size of the placenta. Aberrant concentrations of miR-210 and miR182 were found in preeclamptic placentas delivered at $<37$ weeks of gestation, compared with the concentrations for non-preeclamptic spontaneous preterm deliveries at matched gestation times.

Viruses encode miRNAs that regulate expression of both cellular and viral genes, and contribute to the pathogenic properties of viruses. Numerous human diseases are caused by viral infections, but the intimate relation with the host makes the development of antiviral drugs difficult. Neutralizing the action of viral miRNAs expression by complementary single-stranded oligonucleotides or so-called anti-miRNAs may represent a strategy to combat viral infections and viralinduced pathogenesis. Silencing the action of viral miRNAs may enable the host cell or the immune system to gain control over the virus and even to eliminate the virus. Anti-miRNA oligonucleotides (AMOs) are chemically modified synthetic oligonucleotides that are complementary to their target sequence and this will silence the action of the target. AMOs are easy to produce and relatively cheap, and easy to administer locally (but not systemically). Moreover, they possess low toxicity and are highly specific. Most viral miRNAs identified so far have little homology to each other and to known host cell miRNAs. This reduces the risk of off-target effects of anti-miRNA oligonucleotides and increases the therapeutic potentials of miRNA silencing (Moens, 2009)

\section{QUANTIFICATION OF CIRCULATING CELL-FREE NUCLEIC ACIDS}

Nucleic acids can be identified in plasma, serum, bone marrow aspirates, urine, prostatic fluid, peritoneal fluid, cerebrospinal fluid, bronchial lavage, gastric and biliary juices and stool. With the rapid developments in molecular biology techniques such as realtime quantitative polymerase chain reaction (rt-qPCR), quantitative methylation specific PCR (qMS-PCR), matrix-assisted laser desorption/ionizationtime of flight (MALDIToF) mass spectrometry, quantitative fluorescent PCR (QF-PCR) (Goessl, 2000), digital PCR, single allele primer extension reaction (SAPER) method and BEAMing method and other techniques, the applications in clinical medicine have increased. Go et al. (2008) adapted and applied the Transgenomic 
WAVE System and quencher extension (QEXT) to measure RNA single-nucleotide polymorphism as highly specialized equipment MALDI-TOF, limits the widespread implementation of this powerful RNA single-nucleotide polymorphism.

Freeze thawing and storage at minus 20 ${ }^{\circ} \mathrm{C}$ or minus $80{ }^{\circ} \mathrm{C}$ can lead to reduction in plasma DNA concentration of up to $70 \%$. Future studies should use standardize methodology and large clearly defined patient and control population in order for the result to be interpretable. Serum contains around six times as much amount of free circulating DNA as plasma. So serum is regarded as a better specimen source for circulating cancer related DNA and a biomarker (Umetani, 2006).

\section{Conclusion}

Circulating NA, as markers, are promising for the development of a diagnostic tool because analysis requires blood sample and therefore is relatively noninvasive. A further critical step towards developing circulating NA as a diagnostic tool in body fluids is to assess their performance against conventional techniques in individuals at high risk for disease development. However true nature of circulating NA, etiology, its stability/half life in various body fluids needs special attention. Once these issues are resolved, the evaluation of circulating NA along with other conventional tests will become a cornerstone of an integrative functional approach towards the comprehensive assessment of diseases.

\section{REFERENCES}

An Q, Liu Y, Gao Y, Huang J, Fong X, Li L, Zhang D, Cheng S. 2002. Detection of p16 hypermethylation in circulating plasma DNA of non-small cell lung cancer patients. Cancer Lett, 188: 109114.

Antonatos D, Patsieinakos S. 2006. Cell free DNA levels as a prognostic marker in acute myocardial infarction. Ann. N.Y.Acad. Sci., 1075: 278-281.

Bearzatto A, Conte D, Frattini M, Zaffaroni $\mathrm{N}$, Andriani F, Balestra D, Tavecchio L, Daidone MG, Sozzi G. 2002. p16(INK4A) Hypermethylation detected by fluorescent methylation-specific PCR in plasmas from non-small cell lung cancer. Clin Cancer Res., 8: 3782-3787.

Beau-Faller M, Gaub MP, Schneider A, Ducrocq X, Massard G, Gasser B, Chenard MP, Kessler R, Anker P, Stroun M, Weitzenblum E, Pauli G, Wihlm JM, Quoix E, Oudet P. 2003. Plasma DNA microsatellite panel as sensitive and tumor-specific marker in lung cancer patients. Int. J. Cancer., 105: 361-370.

Bianchi DWF. 1998. DNA in maternal plasma; the plot thickens and the placental barrier thins. Am. J. Hum. Gene., 62 : 763-764.

Biswajit S. 2004. The diagnostic potential of maternal plasma in detecting fetal diseases by DNA test. Indian Journal of Human Genetics, 10(2): 41-45.

Bryzgunova OE, Skvortsova TE, Kolesnikova EV, Starikov AV,. Rykova EY, Vlassov VV and Laktionov PP. 2006. Isolation and comparative study of cell-free nucleic acids from human urine. Ann. N.Y Acad. Sci., 1075: 334-340.

Butt AN, Shalchi Z, Hamaoui K, Samadhan A, Powrie J, Smith. 2006. Circulating nucleic acids and diabetic complications Ann. N.Y.Acad. Sci., 1075: 258-270.

Chan RWY, Wong J, Chan HLY, Mok TSK, Lo WYW, Lee V, To KF, Lai PBS, Rainer TH, Lo YMD, et al. 2010. Aberrant Concentrations of LiverDerived Plasma Albumin mRNA in Liver Pathologies. Clin. Chem., 56: 82-89.

Chim SSC, Shing TKF, Hung ECW, Leung T, Lau T, Chiu RWK, Lo YMD. 2008. Detection and characterization of placental microRNAs in maternal plasma. Clin. Chem., 54: 482-490. 
Dasi F, Martinex-Rodez P, March JA, Santamaria J, Martinez-Javaloyas JM, Fil M, Alino SF. 2006. Real time quantification of human telomerase reverse transcriptase mRNA in the plasma of patients with prostrate cancer. Ann. N.Y. Acad. Sci., 1075: 204-210.

Dominguez G, Carballido J, Silva J, Silva JM, Garcia JM, Menendez J, Provencio M, Espana P, Bonilla F. 2002. p14ARF promoter hypermethylation in plasma DNA as an indicator of disease recurrence in bladder cancer patients. Clin. Cancer Res., 8: 980-985.

Dulaimi E, Hillinck J, Ibanez de CI, AlSaleem T, Cairns P. 2004. Tumor suppressor gene promoter hypermethylation in serum of breast cancer patients. Clin. Cancer Res., 10: 6189-6193.

Esau C, Kang X, Peralta E, Hanson E, Marcusson EG, Ravichandran LV, Sun Y, Koo S, Perera RJ, Jain R, Bennett CF, Lollo B, Griffey R. 2004. MicroRNA-143 regulates adipocyte differentiation. $J$. Biol. Chem., 279: 52361-52365.

Esteller M, Sanchez-Cespedes M, Rosell R, Sidransky D, Baylin SB, Herman JG. 1999. Detection of aberrant promoter hypermethylation of tumor suppressor genes in serum DNA from non-small cell lung cancer patients. Cancer Res., 59: 67-70.

Farina A, Leshane ES, Lambert-Messerlian G M, Jacob A, Cannick JA, Lee T, Neveux LM, Palomaki GE and Bianchi DW. 2003. Evaluation of cell-free fetal DNA as a second- trimester maternal serum marker of down syndrome pregnancy. Clin. Chem., 49(2): 239-242.

Finning K, Martin P, Daniel G. 2004. A clinical service in the U.K to Predict Fetal $\mathrm{Rh}$ (Rhesus) D Blood group using free fetal DNA in maternal Plasma. Ann. N. Y. Acad. Sci., 1022: 119-123.

Fleischhacker M. 2006. Biology of circulating mRNA. Still more questions than answers. Ann. N.Y. Acad. Sci., 1075: 40-49.

Friedman RC, Farh KK, Burge CB, Bartel DP. 2009. Most mammalian mRNAs are conserved targets of microRNAs. Genome Res., 19: 92 -105.

Gal S, Fidler C, Lo YM, Taylor M, Han C, Moore J, Harris AL, Wainscoat JS. 2004. Quantitation of circulating DNA in the serum of breast cancer patients by real time PCR. Br. J. Cancer, 90: 1211-1215.

Gerda E, Gangning L, Ana A, Peter AJ. 2004. Epigenetics in human disease and prospects for epigenetic therapy. Nature, 429: 457-463.

Giacona MB, Ruben GC, Iczkowski KA, Roos TB, Poter DM, Sorenson GD. 1998. Cell-free DNA in human blood plasma; length measurement in patients with pancreatic cancer and healthy controls, Pancreas, 17 : 89-97.

Go ATJI, Visser A. 2008. Measurement of allelic-expression ratios in trisomy 21 placentas by quencher extension of heterozygous samples identified by partially denaturing HPLC. Clin.Chem. 54: 437-440.

Goessl C, Krause H, Muller M, Heicappell R, Schrader M, Sachsinger J. 2000. Fluorescent methylation-specific polymerase chain reaction for DNA-based detection of prostate cancer in bodily fluids. Cancer Res., 60: 5941-5945.

Grady WM, Rajput A, Lutterbaugh JD, Markowitz SD. 2001. Detection of aberrantly methylated hMLH1 promoter DNA in the serum of patients with microsatellite unstable colon cancer. Cancer Res., 61: 900-902.

Hasselmann DO. 2001. Detection of tumorassociated circulating mRNA in serum, plasma and blod cells from patients with disseminated malignant melanoma. Oncol. Rep., 8: 115-118.

Hibi K, Taguchi M, Nakayama H, Takase T, Kasai Y, Ito K. 2001. Molecular detection of p16 promoter methylation in the serum 
of patients with esophageal squamous cell carcinoma. Clin. Cancer Res., 7: 31353138.

Holdenrieder S, Eichhorn P, Beuers U, Samtleben W, Stieber P, Nagel D. 2006. Nucleosomal DNA fragments in autoimmune diseases. Ann. N. Y. Acad. Sci., 1075: 318-327.

Hoon DS, Spugnardi M, Kuo C, Huang SK, Morton DL, Taback BV. 2004. Profiling epigenetic inactivation of tumor suppressor genes in tumors and plasma from cutaneous melanoma patients. Oncogene, 23: 4014-4022.

Hu XC, Wong IH, Chow LW. 2003. Tumorderived aberrant methylation in plasma of invasive ductal breast cancer patients: clinical implications. Oncol. Rep., 10: 1811-1815.

Ichikawa D, Koike H, Ikoma H., Ikoma D, Tani N, Otsuji E, Kitamura K, Yamagishi H. 2004. Detection of aberrant methylation as a tumor marker in serum of patients with gastric cancer. Anticancer Res., 24: 2477-2481.

Issa JJ. 2007. DNA methylation as a therapeutic target in cancer. Clin. Cancer Res., 13(6): 1634-1637.

Johnson PJ, Lo YMD. 2002. Plasma nucleic acids in the diagnosis and management of malignant disease. Clin. Chem., 48(8): 1186-1193.

Kanyama Y, Hibi K, Nakayama H, Kodera Y, Ito K, Akiyama S. 2003. Detection of p16 promoter hypermethylation in serum of gastric cancer patients. Cancer Sci., 94: 418-420.

Kato M, Arce L, Natarajan R. 2009. microRNAs and their role in progressive kidney diseases. Clin. J. Am. Soc. Nephrol., 4: 1255-1266.

Kawakami K, Brabender J, Lord RV, Groshen S, Greenwald BD, Krasna MJ. 2000. Hypermethylated APC DNA in plasma and prognosis of patients with esophageal adenocarcinoma. J. Natl. Cancer Inst., 92: 1805-1811.
Kazuaki M, Toshikazoo M. 2005. Diagnostic and therapeutic applications of epigenetic. Japanese Journal of Clinical Oncology, 35(6): 293-301.

Koike H, Ichikawa D, Ikoma H, Otsuji E, Kitamura K, Yamagishi H. 2004. Comparison of methylation-specific polymerase chain reaction (MSP) with reverse transcriptase-polymerase chain reaction (RT-PCR) in peripheral blood of gastric cancer patients. J. Surg. Oncol., 87: 182-186.

Kotsch K, Mashreghi MF, Bold G, Tretow P, Beyer J, Matz M, Hoerstrup J, Pratschke J, Reinke R. 2004. Enhanced granulysin mRNA expression in urinary Sediment in early and delayed acute renal allograft rejection. Transplantation, 77: 18661875.

Kurakawa E, Shimamoto T, Utsumi K, Hirano T, Kato H, Ohyashiki K. 2001. Hypermethylation of p16(INK4a) and p15(INK4b) genes in non-small cell lung cancer. Int. J. Oncol., 19: 277-81.

Lagos-Quintana M, Rauhut R, Lendeckel W, Tuschl T. 2001. Identification of novel genes coding for small expressed RNAs. Science, 294: 853-858.

Lam NYL, Timothy H, Rainer TH, Chiu RWK, Joynt GM, Lo YMD. 2004. Plasma mitochondrial DNA concentration after trauma. Clin. Chem., 50: 213-216.

Lau NC, Lim LP, Weinstein EG, Bartel DP. 2001. An abundant class of tiny RNAs with probable regulatory roles in Caenorhabditis elegans. Science, 294: 858-862.

Lecomte $\mathrm{T}$, Berger A, Zinzindohoue $\mathrm{F}$, Micard S, Landi B, Blons H, Beaune P, Cugnenc PH, Laurent-Puig P. 2002. Detection of free-circulating tumorassociated DNA in plasma of colorectal cancer patients and its association with prognosis. Int. J. Cancer, 100: 542-548.

Lee TL, Leung WK, Chan MW, Ng EK, Tong, JH, Lo KW, Chung SC, Sung JJ, To KF. 2002. Detection of gene promoter 
hypermethylation in the tumor and serum of patients with gastric carcinoma. Clin. Cancer Res., 8(6): 1761-1766.

Li Y, Zimmermann B, Rusterholz C, Kang A, Holzgreve W, Hahn S. 2004. Size separation of circulatory DNA in maternal plasma permits ready detection of fetal DNA Polymorphism. Clin. Chem., 50: 1002-1011.

Lin JC, Wang WY, Chen KY, Wei YH, Liang WM, Jan JS, Jiang RS. 2004. quantification of plasma Epstein. Barr virus DNA in patients with advanced nasopharyngeal carcinoma. $N$. Eng. J. Med., 350 : 2461-2470.

Liu Y, An Q, Li L, Zhang D, Huang J, Feng X, Cheng S, Gao Y. 2003. Hypermethylation of p16INK4a in Chinese lung cancer patients: biological and clinical implications. Carcinogenesis 24(12): 1897-1901.

Lledo SM, Garcia-Granero E, Dasi F, Ripoli R, Garcia SA, Cervantes A, Alino SF. 2004. Real time quantification in plasma of human telomerase reverse transcriptase (hTERT) mRNA in patients with colorectal cancer. Colorectal Dis. 6: 236242.

Lo YM. 1999. Quantitative abnormalities of fetal DNA in maternal serum in preeclampsia. Clin. Chem., 45: 184-188.

Lo YMD, Corbetta N, Chamberlain PF, Sargent JL. 1997. Presence of fetal DNA in maternal plasma and serum. Lancet, 350: $485-487$.

Lo YMD. 2006. Fetal DNA in maternal plasma progress through epigenetics. Ann. N.Y. Acad. Sci., 1075: 74-80.

Lo YMD. Chiu RWK. 2008. Noninvasive prenatal diagnosis of fetal chromosomal aneuploidies by maternal plasma nucleic acid analysis. Clinical Chemistry, 54: 461-466.

Miura N. 2003. Senstive detection of human telomerate reverse transcriptase mRNA in the serum of patients with hepatocellular carcinoma. Oncology, 64: 430-434.
Moens U. 2009. Silencing viral microRNA as a novel antiviral therapy? Journal of Biomedicine and Biotechnology, 2009: 119.

Mulcahy HE, Lyautey J, Lederrey C, qi Chen $\mathrm{X}$, Anker P, Alstead EM, Ballinger A, Farthing MJ, Stroun M. 1998. A prospective study of K-ras mutations in the plasma of pancreatic cancer patients. Clin. Cancer Res., 4: 271-275.

Muthukumar T, Dadhania D, Ding R, Snopkowski C, Naqvi R, Lee JB, Hartono C, Li B, Sharma VK. 2005. mRNA for FOXP3 in the urine of renal-allograft recipients. N. Engl. J. Med., 353: 23422351.

Nakayama H, Hibi K, Taguchi M, Takase T, Yamazaki T, Kasai Y, Ito K, Akiyama S, Nakao A. 2002. Molecular detection of p16 promoter methylation in the serum of colorectal cancer patients. Cancer Lett., 188: 115-119.

Ng CS, Zhang J, Wan S, Lee TW, Arifi AA, Mok T. 2002. Tumor p16M is a possible marker of advanced stage in non-small cell lung cancer. J. Surg. Oncol., 79: 101106.

$\mathrm{Ng}$ EKO. 2003. The concentration of circulating corticotrophin releasing hormone mRNA in maternal plasma in increased in preeclampsia. Clin Chem., 49: 727-731.

Ng EKO, Chong WWS, Jin H, Shin VY, Yu J, Poon TC, Ng SS, Sung JJ. 2009. Differential expression of microRNAs in plasma of patients with colorectal cancer: a potential marker for colorectal cancer screening. Gut, 58(10): 1375 - 1381.

Nomoto S, Yamashita K, Koshikawa K, Nakao A, Sidransky D. 2002. Mitochondrial D-loop mutations as clonal markers in multicentric hepatocellular carcinoma and plasma. Clin. Cancer Res., 8: 481-487.

Novakovic S. 2004. Detection of telomerase RNA in the plasma of patients with breast 
cancer, malignant melanoma or thyroid cancer. Oncol. Rep., 11: 245-252.

Pan PD, Peter I, Lambert-Messerlian GM, Canick JA, Bianchi DW, Johnson KL. 2005. Cell-free fetal DNA levels in pregnancies conceived by IVF. Hum. Reprod., 20: 3152-3156.

Pandey AK, Agarwal P, Kaur K, Datta M. 2009. MicroRNAs in diabetes: tiny players in big disease. Cell Physiol. Biochem., ,23: 221-232.

Papadopoulou E, Davilas E, Sotiriou V, Koliopanos A, Aggelakis F, Dardoufas K, Agnanti NJ, Karydas I, Nasioulas G. 2004. Cell-free DNA and RNA in plasma as a new molecular marker for prostrate cancer. Oncol. Res., 14: 439-445.

Paranjape T, Slack FJ, Weidhaas JB. 2009. MicroRNAs: tools for cancer diagnostics Gut, 58: 1546-1554.

Park NJ, Zhou H, Elashoff D. 2009. Salivary microRNA: Discovery, characterization, and clinical utility for oral cancer detection .Clin. Cancer Res., $\quad$ 15(17): 5473 - 5477.

Pornthanakasem W, Shotelersuk K, Termrungruanglert W, Voravud N, Niruthisard S, Mutirangura A. 2001. Human papillomavirus DNA in plasma of patients with cervical cancer. $B M C$ Cancer, 1: 2.

Poy MN, Hausser J, Trajkovski M, Braun M, Collins S, Rorsman P, Zavolan M, Stoffel M. 2009. miR-375 maintains normal pancreatic alpha- and beta-cell mass. PNAS, 106(14): 5813-5818.

Rainer TH, Lam NY. 2006. Circulating Nucleic Acids and Critical illness. Ann. N.Y.Acad. Sci., 1075: 271-277.

Rijnders RJ, Vander SCE, Bossers B, de Vroede MA, Christiaens GC. 2001. Fetal sex determination from maternal plasma in pregnancies a risk for congenial adrenal hyperplasia. Obstet Gynaecol., 98: 374-378.

Sanchez-Cespedes M, Esteller M, Wu L, Nawroz-Danish H, Yoo GH, Koch WM,
Jen J, Herman JG, Sidransky D. 2000. Gene promoter hypermethylation in tumors and serum of head and neck cancer patients. Cancer Res, 60: 892-895.

Sekizawa A, Tarina A, Sugito Y. 2004. Proteinuria and hypertention are independent factors affecting fetal DNA values. A retrospective analysis of afftected and unaffected patients. Clin. Chem., 50(1): 221-224.

Schmidt B. 2004. Detection of cell-free nucleic acids in bronchial lavage fluid supernatants from patients with lung cancer. Eur. J. Cancer, 40: 452-460.

Silva JM, Dominguez G, Garcia JM, Gonzalez R, Villanueva M., Navarro F. 1999. Presence of tumor DNA in plasma of breast cancer patients: clinicopathological correlations. Cancer Res., 59: 3251-3256.

Silva JM. 2001. Detection of epithelial messenger RNA in the plasma of breast cancer patients is associated with poor prognosis tumor characteristics. Clin. Can. Research.7: 2821-2825.

Silva JM, Garcia JM, Dominguez G, Silva J, Miralles C, Cantos B. 2002. Persistence of tumor DNA in plasma of breast cancer patients after mastectomy. Ann. Surg. Oncol., 9: 71-76.

Silva JM, Dominguez G, Villanueva MJ, Gonzalez R, Garcia JM, Corbacho C. 1999. Aberrant DNA methylation of the p16INK4a gene in plasma DNA of breast cancer patients. Br. J. Cancer, 80: $1262-$ 1264.

Stroun M, Anker P, Mourice P, Lyautey J, Lederrey C, Beljanski M. 1989. Neoplastic characteristics of the DNA found in the plasma of cancer patients. Oncology, 46: 318-322.

Sueoka E. 2005. Detection of plasma hnRNP B1 mRNA, a new cancer biomarker, in lung cancer patients by quantitative realtime polymerase chain reaction. Lung Cancer, 48: 77-83.

Taback B. 2001. Microsatelite alterations detected in the serum of early stage breast 
cancer patients. Ann. N.Y. Acad. Sci, 945: 22-30.

Tong Yu K, Chunming D, Rossa WKC, Ageliki G, Stephen SCC, Tak YL, Tse NL, Tze KL, Kypros HN, Lo YMD. 2006. Non-invasive prenatal detection of fetal trisomy 18 by epigenetic allelic ratio analysis in maternal plasma: theoretical and empirical considerations. Clin. Chem., 52(12): 2194-2202.

Umetani N, Hiramatsu S, Hoon DSB. 2006. Higher amounts of free circulating DNA in serum than in plasma is not mainly caused by contaminated extraneous DNA during separation. Ann. N.Y. Acad. Sci., 1075: 299-307.

Umetani N, Giluliano AE, Hiramatsu S, Farin Amersi Taku FA. 2006. Prediction of breast tumor progression by integrity of free circulating DNA serum. Journal of Clinical Oncology, 24: 4270-4276.

Usadel H, Brabender J, Danenberg KD, Jeronimo C, Harden S, Engles J, 2002. Quantitative adenomatous polyposis coli promoter methylation analysis in tumor tissue, serum, and plasma DNA of patients with lung cancer. Cancer Res., 62: $371-375$.

Valenzuela MT, Galisteo R, Zuluaga A, Villalobos M, Nunez MI, Oliver FJ. 2002. Assessing the use of p16 (INK4a) promoter gene methylation in serum for detection of bladder cancer. Eur. Urol., 42: 622-628,

Vasioukhin V, Anker VP, Maurice P, Lyautey J, Lederrey C, Stroun M. 1994. Point mutations of the N-ras gene in the blood plasma DNA of patients with myelodysplastic syndrome or acute myelogenous leukaemia. $B r . \quad J$. Haematol., 86: 774-779.

von Knoblock R, Hegele A, Heidrun B, Olbert P, Heidenreich A, Hofmann R. 2001. Serum DNA and urine DNA alterations of urinary transitional cell bladder carcinoma detected by fluorescent microsatellite analysis. Int. J. Cancer, 94: 67-72.

Wataganara T. 2003. Maternal serum cell-free fetal DNA levels are increased in case of trisomy 13 but not trisomy 18. Hum. Genet., 112: 204-208.

Wataganara T. 2004. Inverse correlation between maternal weight and second trimester circulating cell-free fetal DNA levels. Obstet. Gynecol., 104: 545-550.

Wang BG, Huang HY, Chen YC, Bristow RE, Kassauei K, Cheng CC, Roden R, Sokoll LJ, Chan DW, Shih IM. 2003. Increased plasma DNA integrity in cancer patients. Cancer Res., 63(14): 3966-3968.

Wong CKB, Rossa WKC, Nancy BYT, Chan KCA, Lin WC, Tze KL, Tse NL, LO YMD. 2005. Circulating placental RNA in maternal plasma is associated with a preponderance of 5' mRNA fragments: implications for noninvasive prenatal diagnosis and monitoring. Clin. Chem., 51(10): 1786-1795.

Wong TS, Chang HW, Tang KC, Wei WI, Kwong DL, Sham JS. 2002. High frequency of promoter hypermethylation of the death-associated protein-kinase gene in nasopharyngeal carcinoma and its detection in the peripheral blood of patients. Clin Cancer Res., 8: 433-437.

Wong IH, Lo YM, Yeo W, Lau WY, Johnson, P.J. 2000. Frequent p15 promoter methylation in tumor and peripheral blood from hepatocellular carcinoma patients. Clin. Cancer Res., 6: 35163521.

Wong IH, Zhang J, Lai PB, Lau WY, Lo YM. 2003. Quantitative analysis of tumorderived methylated p16INK4a sequences in plasma, serum, and blood cells of hepatocellular carcinoma patients. Clin. Cancer Res., 9: 1047-1052.

Wong IH, Lo YM, Zhang J, Liew CT, Ng MH, Wong N. 1999. Detection of aberrant p16 methylation in the plasma and serum of liver cancer patients. Cancer Res., 59: 71-73. 
Wong SC. 2004. Quantification of plasma beta-catenin mRNA in colorectal cancer and adenoma patients. Clin. Cancer Res., 10: $1613-1617$.

Wong TS, Kwong DL, Sham JS, Wei WI, Kwong YL, Yuen AP. 2004. Quantitative plasma hypermethylated DNA markers of undifferentiated nasopharyngeal carcinoma. Clin. Cancer Res., 10: 2401-2406.

Wong TS, Man MW, Lam AK, Wei WI, Kwong YL, Yuen AP. 2003. The study of p16 and p15 gene methylation in head and neck squamous cell carcinoma and their quantitative evaluation in plasma by real-time PCR. Eur. J. Cancer, 39: 18811887.

Xu Ji, Rie T, Yumiko H, Go H, Yasue F, Naoharu I. 2009. Plasma mir-208 as a biomarker of myocardial injury. Clin. Chem., November 1, 55(11): 1944 - 1949.

Yang H, Dinney CP, YeY, Zhu Y, H, Grossman B, Wu X. 2008. Evaluation of genetic variants in microRNA-related genes and risk of bladder cancer. Cancer Res., 68: 2530- 2537.
Yamaguchi S, Asao T, Nakamura J, Ide M, Kuwano H. 2003. High frequency of DAP-kinase gene promoter methylation in colorectal cancer specimens and its identification in serum. Cancer Lett., 194: 99-105.

Zhong S, Ng MC, Lo YMD, Chan JC, Johnson PJ. 2000. Presence of mitochrondrial tRNA (Leu(UUR)) A to $g$ 3243 mutation in DNA extracted from serum and plasma of patients with type 2 diabetes mellitus. J Clin. Path., 53: 466469.

Zou HZ, Yu BM, Wang ZW, Sun JY, Cang, H, Gao F. 2002. Detection of aberrant p16 methylation in the serum of colorectal cancer patients. Clin Cancer Res., 8: 188-199. 